Ronald B. Mitchell. "International Environment" In Handbook of International Relations. Editors: Thomas Risse, Beth Simmons, and Walter Carlsnaes. Sage Publications, 2002, 500-516.

\title{
26
}

\section{International Environment}

\author{
R O N A L B. M I T C H E L L
}

What political, economic and social forces cause the variety of international environmental problems we face? Why do some of these environmental problems become international issues while others do not? What explains why solutions are devised for some of these international problems but not for others? Why do some of the international policies devised mitigate, and sometimes eliminate, the problems they address while others fail miserably? Finally, what determines global society's success at evaluating and improving its attempts to protect the global environment? These questions regarding five stages of the international policy process constitute the primary focus of a growing literature on international environmental politics and policy (IEP).

Scholars working in this sub-field face an uneasy tension between pessimism and optimism: pessimism borne from recognizing that structural factors often dictate international environmental outcomes; perhaps unwarranted optimism borne from observing that human agency has sometimes protected the natural environment and from believing that humans can make better choices. Thus, issues of structure and agency central to the field of international relations (IR) also frame much IEP research (Dessler, 1989; Wendt, 1987). Fully understanding outcomes, and how they vary over policy stages, requires recognition that structures constrain the choices agents can make but leave room for political skill and energy in determining which of a more or less narrow range of potential outcomes actually occurs (Keohane, 1996: 24; Underdal, 2001: 37). Equally important, human choices, over time, can transform 'normally invariant' structural forces that 'shape how publics and officials ... experience and cope with the diverse challenges posed by environmental issues' (Dessler, 1989: 461; Rosenau, 1993: 262).
Dividing the literature on IEP into 'policy stages' serves more than merely as an organizational tool. The usual distinctions of rationalism and constructivism; realism, institutionalism, and liberalism; or power-based, interest-based and knowledge-based certainly apply to IEP (Hasenclever et al., 1997; Ruggie, 1998). Yet, within IEP, differing theoretical, normative, and methodological perspectives generally coexist in complementary ways that enrich our understanding of global environmental politics. Thus, analyzing the literature along lines of policy process mirrors its tendency to cut across traditional boundaries with mid-range theory that pays careful attention to policy issues. Most importantly, a policyprocess approach highlights how structural constraints on choices, on the one hand, and the participation, choices, and influence of state and nonstate actors, on the other, vary across policy stages.

\section{A Brief History of the Field}

The nature of international environmental problems makes IEP interdisciplinary, extending from the natural sciences to philosophy and religion. Several textbooks cover the issues broadly (Conca et al., 1996; Hurrell and Kingsbury, 1992; Vig and Axelrod, 1999), while others narrate the history of environmental politics, describe environmental problems, propose policy solutions, and exhort greater efforts to protect the environment (Porter and Brown, 1991; Soroos, 1999; World Resources Institute, 1992-3). The work of international lawyers (Birnie and Boyle, 1992; Cameron et al., 1996; Sands, 1994) and economists (Barrett, 1994; Swanson and Johnston, 1999) complements and 
informs political science. Yet, to do justice to that sub-set of the literature concerned primarily with causal explanations of IEP, I exclude many of these important literatures from this review.

The study of international environmental issues only gained recognition among international relations scholars in the late 1980s. A few scholars addressed IEP during the 1970s and 1980s (Caldwell, 1984; Falk, 1971; Kay and Jacobson, 1983; M'Gonigle and Zacher, 1979; Ophuls, 1977; Orr and Soroos, 1979; Sprout and Sprout, 1971; Young, 1981). With the exception of a special issue of International Organization on 'International Institutions and the Environmental Crisis' in 1972 (coinciding with the UN Conference on the Human Environment), IEP articles in major IR journals were infrequent. This changed rapidly around 1989, in no small part due to Peter Haas's work developing John Ruggie's notion of epistemic communities to explain the Mediterranean Action Plan (Haas, 1989; Haas, 1990: 55 n. 22; Ruggie, 1975). Indeed, Haas's work is a rare case in which theories developed within IEP have influenced IR scholarship generally, instead of vice versa (Haas, 1992b).

The end of the Cold War and the 1992 UN Conference on Environment and Development (UNCED) made international environmental issues both politically and intellectually more salient. Two journals dedicated to the issues were launched, International Environmental Affairs and the Journal of Environment and Development, and IEP articles became more common in mainstream journals and edited volumes devoted to international relations. Sole-authored and edited books dedicated to international environmental issues became increasingly common (Choucri, 1993; Haas et al., 1993; Lipschutz and Conca, 1993; Young, 1994; Young and Osherenko, 1993). A new crop of scholars began publishing doctoral and subsequent research (Bernauer, 1995; Dauvergne, 1997; Keohane and Levy, 1996; Litfin, 1994; Miller, 1995; Mitchell, 1994a; O’Neill, 2000; Princen, 1996; Sprinz and Vaahtoranta, 1994; Wapner, 1996; Young, 1998b). Indeed, recent growth in the amount and diversity of the literature has made it increasingly difficult to track.

As in the early stages of most sub-fields, the gener ation of theoretical propositions has outpaced their operationalization and testing. New terms and taxonomies overlap with, but seem unaware of, earlier ones. The major debates that structure most sub-fields have yet to emerge, in part because key concepts and theories are not yet refined enough to generate competing predictions. Theories are tested through single cases with insufficient attention to variable definition, case selection and generalizability (Mitchell and Bernauer, 1998). Databases to allow large- $N$ studies are only now being developed. But the sub-field is maturing in ways that, if continued, will remedy these shortcomings.

\section{Causes of International}

Environmental Problems

Growth in the number and magnitude of harms humans inflict on the natural environment and in our awareness of those harms has produced a plethora of theories on why international environmental problems are both ubiquitous and increasing. Some analysts see the increase in international environmental problems and variation across countries and issues within that trend as functions of the relationship between the supply of environmental amenities and the demands placed on them. Since Malthus, people have recognized that both the carrying capacities of natural systems (the amount and rate at which they can supply human demands) and the magnitude and types of human demands placed on them vary (Malthus and Appleman, 1976). These supply-demand conflicts are exacerbated because capitalist, socialist and communist economies actively create incentives to disregard the environment and passively fail to remedy situations involving Tragedies of the Commons and other externalities, that is, situations involving actions that bestow benefits on those who engage in them but impose larger costs on society as a whole (Hardin, 1968).

Others see sovereignty and international anarchy as making states even more likely than individuals to generate negative externalities by leading them to worry about relative, not absolute, gains and security rather than environmental protection (Conca, 1994; Litfin, 1998). Governance structures are less available, effective and robust at the international, than domestic, level. The security concerns of states and the profit motive of multinational corporations (MNCs) incline both to disregard environmental protection unless pressed by environmental movements and non-governmental organizations (NGOs) (Lipschutz and Conca, 1993; Lipschutz and Mayer, 1996). Scholars developing deep ecology, ecofeminism and other 'radical ecologies' further identify environmental degradation as merely the inherent and predictable result of the increasing domination of modernity and Western normative structures that devalue nature (Devall and Sessions, 1985; Merchant, 1996; Naess, 1973).

If structural forces make environmental degradation likely, they leave room for human actions that avoid it being inevitable. Policies cannot change carrying capacities but can shape demands on natural systems to better reflect them. Intergovernmental regulation or transnational civil society can create constraints and incentives to induce internalization of externalities. Over time, individuals and groups can consciously transform the values of global society to reflect environmental concerns (Stokke, 1998: 140). Research can remedy 
problems that stem from ignorance of human impacts on the environment and can identify new ways of meeting human needs sustainably. Although theories regarding the sources of international environmental problems are implicit in the theories regarding their resolution outlined below, there is considerable room for political scientists to develop a more complete and integrated theory of the political, social, cultural and economic forces that lead environmental problems to appear in some regions and issue areas but not in others, and to appear with increasing regularity around the globe.

\section{Agenda-SETTING}

Why do only some of the many human impacts on the global environment capture international political and policy attention? Why do some that receive policy attention later 'vanish without a trace' while others are actively addressed? And, what determines how issues are discussed, whether in economic, moral, equity, or other framings?

\section{Structural Forces and Constraints}

Political context, material characteristics of the issue and immediate catalysts are three major determinants of the political attention devoted to a problem. Broad contextual factors alter the ease with which environmental issues gain attention. Trends in economic, cultural and informational interdependence, and in views of government's role in economic and social affairs, have made environmental issues politically more important. The end of the Cold War created more diplomatic space for environmental issues. Trade liberalization has created pressures to harmonize environmental standards. Increased awareness of environmental problems has fostered a proliferation of environmental conferences and negotiations (Meyer et al., 1997). The rise of 'post-material values' in civil societies of agenda-setting states has expanded the number, type, geographic scope and time horizon of environmental problems being addressed (Inglehart, 1995).

Contextual factors also influence the discourse of an issue, and the discursive context itself influences how issues play on the policy agenda. A precautionary discourse (that encourages environmental protection despite scientific uncertainty regarding the magnitude and causes of environmental harm from human activities) can move problems onto the agenda and toward policy action more quickly than traditional discourses that require scientific certainty before taking action (Litfin, 1994: 10). Although we have yet to determine why certain framings become dominant, it is clear that different framings can influence whether states view a problem as involving irreconcilable values or a jointly sub-optimal outcome, with the latter view helping states go beyond recognizing the problem to seeking solutions (Young, 1998a: 70).

If contextual forces explain broad patterns in agendas, a problem's material characteristics help explain variation within those patterns. We can expect environmental problems involving transboundary impacts, large and dramatic risks or direct and immediate threats to humans, and clearly understood trends, sources and solutions to appear on the international agenda more often than those lacking such traits. Environmental concern reflects 'objective' impacts on, and 'subjective' valuation of, an environmental amenity as well as the perceptions and incidence of the costs and benefits of mitigating the harm, factors that vary across issues and across and within countries (Jasanoff, 1986).

Paralleling other realms, powerful actors' interests are most likely to gain international attention. Environmental problems, even those with readily available solutions, often remain unaddressed if their costs, however great, are borne by developing countries. Fresh water supply, indoor air pollution and pollution-related illness kill millions of people annually in the developing world but remain unaddressed while international policy focuses on ozone depletion and other issues that pose smaller and more distant risks. Environmental problems in developing countries tend to garner attention only when people in agenda-setting states become concerned and, even then, these issues may languish or fail to lead to adequate solutions.

Variation in the level and type of environmental concern around the globe usually demands linkages among interests to get on the agenda (Young, 1998a: 57, 83). Governments, scientists, NGOs and individuals can link local environmental impacts and concerns to broader political agendas (Princen and Finger, 1994). Discursive links can make states more willing to work toward problem resolution, as when developing states attended UNCED because it successfully linked environment and development (World Commission on Environment and Development, 1987). More tactical links also can work, as evident in the financial mechanisms of several recent treaties and the participation of Soviet bloc states in European acid rain negotiations in the 1970s to promote détente (Levy, 1993).

One consistent, though undertheorized, finding of much IEP literature is that crises, accidents and other shocks prompt policy action by clearing 'a space for the consideration of new ideas on how to explain and solve problems' (Litfin, 1994: 185). International negotiations promptly followed the Chernobyl nuclear accident, the Sandoz spill in the Rhine, forest die-off in Germany and North Sea algae blooms. Scientific breakthroughs can also put issues on the agenda or increase their urgency 
(Keohane, 1996: 27). The press mediates the influence of such events, headlining some issues while relegating others to the back pages. To give but one example, maritime regulation has quickly followed pollution incidents near developed states even though much larger disasters off Africa and Latin America had occurred many years before. Yet, catalysts have heavily contingent causal powerthey 'are not driving forces like material conditions, interests, or ideas' but move things forward only when deeper forces and conditions align (Haas, 1992b: 14; Young, 1998a: 77). Obviously, more systematic analysis would allow us to take such vague claims and identify more precisely whether catalytic events are necessary for policy action, what types are most influential and what factors and processes condition their influence.

\section{Agents as Policy Entrepreneurs}

Astute politicians, of course, do not simply wait for catalytic events to occur (Connolly, 1996: 364). Individuals, NGOs, states and international organizations consciously and strategically expend 'political capital in an effort to persuade others to recognize [certain] issues as priority agenda items' (Young, 1998a: 7; see also Risse, 2001). Scientists and the epistemic communities they compose can raise concern by clarifying environmental impacts and proposing solutions (Haas, 1990: 224). Although the legitimacy accorded to scientific research and discourse allows global environmental assessments to have considerable influence on the environmental agenda, as evident with the reports of the Intergovernmental Panel on Climate Change, many assessments still 'sink without a trace' (Corell, 1999; Shea, 1997). Nor are the biases and parochial interests that we expect from industry and NGO lobbyists always absent from scientific inputs to the policy process (Boehmer-Christiansen and Skea, 1991).

NGOs provide information, conduct research and propose and evaluate policies, transmitting both ideas and political pressure between polities and governments (Princen and Finger, 1994; Raustiala, 1997c). Pressure from American NGOs led the World Bank to add environmental concerns to project approval processes (McCormick, 1999: 65). The International Union for the Conservation of Nature (IUCN), the Worldwide Fund for Nature (WWF) and the World Resources Institute (WRI) self-consciously sought to make biodiversity an international issue, in part by conducting their own scientific research (Raustiala, 1997b). Although NGOs certainly can influence the debate, we still lack models that clarify the conditions and factors that facilitate or impede such influence.

Interest groups in powerful, agenda-setting states can make domestic issues international
(DeSombre, 2000; Schreurs and Economy, 1997). Environmental movements in former Soviet bloc states coupled environmental concerns with nationalist movements to link domestically legitimate forms of discourse with transnational environmental concerns (Dawson, 1996). Corporations often support international actions to delay unilateral regulations, replace them with less stringent international ones, and avoid the economic costs of unilateral action (DeSombre, 2000).

In response to such efforts or on their own, states, individual bureaucratic entrepreneurs and international organizations often initiate and maintain pressure for international action. Regimes on Arctic environmental cooperation exhibit such state leadership even without epistemic community or NGO pressure (Young, 1998a: 7, 76). International regimes develop expertise and focus resources on certain issues. The UN Environment Program (UNEP) has promoted several regional seas agreements. Both the Convention on Long-Range Transboundary Air Pollution (LRTAP) and the International Maritime Organization have negotiated agreements on many atmospheric and marine pollutants, respectively, even in the absence of catalyzing events. In a spillover-type process, international cooperation to prevent a particular type of pollution or protect a particular species seems to promote cooperation on other pollutants and species.

States and international institutions generally do not look for problems to resolve but respond to issues put before them by environmental crises or by the activism of scientists, NGOs or individuals. Although some actors wield more influence, many actors have at least some. The international policy agenda is neither a systematic ranking of global environmental risk nor simply a list of problems whose resolution provides large benefits and entails few costs. Costs and benefits matter, but subtle and deeply embedded biases in the problems scientists study influence whether we become aware of or develop solutions to a problem. 'Mundane' problems and 'mundane' solutions receive less attention than issues on the cutting edge of science and technology (Kammen and Dove, 1997). The policy agenda reflects the goals, funding incentives and expertise of all the activists, politicians and bureaucrats involved. What issues ultimately get addressed and how they are prioritized reflect the interests of states but also reflect the pressures of multiple interest groups and the simple influence of catalytic events.

\section{Framing of Issues on the Agenda}

Precisely because the question of how to define and address a problem 'is up for grabs' during agenda formation, framing is crucial to what issues get on the agenda and how they progress through the policy 
process (Young, 1998a: 23, 83). Successful framing makes environmental concerns more salient to those not otherwise interested (Sebenius, 1983; Young, 1998a: 82). Although material factors constrain how a problem can be defined and delimit possible policy solutions, scientists, NGOs and governments can still wield influence within those constraints (Litfin, 1994: 9). Problems can be framed as regional or global, as symmetric Tragedies of the Commons (where all parties are both victims and perpetrators) or asymmetric externalities (where some parties are victims and others are perpetrators), a stand-alone problem or an ecosystemic one, or deserving weak regulation or a complete ban. Which framing is chosen, in turn, influences whether the problem garners attention, how broadly or narrowly the problem is defined, and what responses are considered.

Issue framing involves a dynamic political struggle between 'various networks of power/knowledge' in which policy-makers and stakeholders interpret and frame knowledge 'in light of specific interests, so that information begets counterinformation' (Litfin, 1994: 8 and 13; Stokke, 1998: 135). But, we know very little about 'the process through which a discourse crystallizes around a problem on the international political agenda', or how and when rhetorical power resources can overthrow more material resources to replace dominant discourses with alternative ones (Litfin, 1994: 10; Young, 1998a: 189). Analysis of why issues get onto and become prominent on the international stage and why they are debated and discussed in the terms they are remains in its infancy. Moving forward in this arena will require developing more specific, contingent and testable propositions about why certain environmental problems remain unaddressed and prescriptions about how that might change.

\section{Policy Formulation}

Consensus about a problem's existence, causes and importance need not create consensus regarding what, or even whether, action is warranted. The efforts of those most concerned about an issue, whether they be states or non-state actors, often fail to prompt international action. I focus here on factors that facilitate or hinder inter-state regime formation but also note state unilateralism, direct NGO activism and MNC voluntarism as alternatives to inter-state efforts.

\section{Structural Determinants of Regime Formation}

Explaining regime formation has been a major focus of neo-institutionalism, especially its international environmental variant. Most IEP scholars, due to theoretical predispositions or convinced by environmental evidence, accept the institutionalist claim that inter-state cooperation is difficult but possible and focus on identifying factors that make it more likely. Realists, on the other hand, have largely ignored international environmental cooperation, taking one of three positions: (a) relative gains concerns hinder cooperation as much in environmental affairs as in other realms (Waltz, 1979: 195ff); (b) the 'low politics' of environmental issues are outside the domain of realist claims; or (c) the 'low politics' of environmental issues have so little impact on state survival that states can afford to pursue absolute gains.

Refining more general IR arguments, many IEP scholars have investigated the influence of the structure of interests on regime formation and design. Questioning the common assumption that international environmental problems are all Tragedies of the Commons, scholars have proposed various typologies of interest configurations and conflict types to explain the likelihood of regime formation. Proposals that problems can be identified as ranging from benign to malign (Underdal, 2001; Young, 1999b: 118) have fostered careful empirical research that allows independent categorization of problems in ways that help explain why regimes arise to resolve some problems but not others (Miles and Underdal, 2001; Wettestad, 1999; Young, 1998a).

The malign-benign distinction is too blunt a tool, however, to predict what type of regime will form. That requires using the more specific design implications provided by such distinctions as those among assurance, coordination, collaboration and suasion games; coordination and incongruity problems; symmetric and asymmetric problems; conflicts over values, means, relatively assessed goods, and absolutely assessed goods; and commons problems, shared natural resource problems and transboundary externalities (Barkin and Shambaugh, 1999; Hasenclever et al., 1997; Martin, 1992b; Underdal, 2001). Specific compliance mechanisms should be more common in regimes addressing collaboration games and compelling focal points more common in those addressing coordination games (Zürn, 1998: 629). Symmetric Tragedies of the Commons should lead to reciprocity being used while asymmetric problems (involving perpetrators who are not also victims) should lead to positive incentives being used (Mitchell and Keilbach, 2001). Compromise solutions that set maximum thresholds for harmful activities have become less common as policy-makers realize that only complete bans can adequately address unpredictable and irreversible environmental problems (Princen, 1996: 150-2). Of course, the implications of many other distinctions continue to need development.

At this point, empirical assessment of competing predictions about what kind of regime will form requires carefully identifying what kind of problem 
states face. That, in turn, requires carefully identifying state preferences independent of their policy positions and identifying the pattern of those preferences across states to identify the structure of the problem being addressed. The benefits and costs of international regulation help predict state positions as leaders or laggards (Levy, 1993; Sprinz and Vaahtoranta, 1994: 78). But preferences for environmental protection also vary based on factors as varied as policy styles, party politics, bureaucratic structures, industrial interests, NGOs and transnational linkages (DeSombre, 2000; O'Neill, 2000; Schreurs and Economy, 1997). These and other factors influence the value individual states place on environmental protection and the constellation of levels of concern which influences the ability to reach agreement and the shape of agreements reached. Categorizing real-world environmental problems as involving a Tragedy of the Commons, an asymmetry of interests, a conflict over a relatively assessed good, or a suasion game involving powerful actors attempting to assert their interests requires careful attention to actor preferences that avoids the tendency toward superficial and aggregate analogizing (Hasenclever et al., 1997; Martin, 1992a; Underdal, 2001). Many environmental problems involve intertwined strategic problems, as with stratospheric ozone loss, which may best be characterized as a Tragedy of the Commons among concerned developed states and an asymmetric externality between these states and less concerned, 'upstream', developing states (Mitchell and Keilbach, 2001).

Preferences also influence the aggressiveness of regime goals. States will find it easier to form a regime if they have low ambitions for it. Regimes initiated with framework conventions, cooperative research programs, or non-binding agreements (Brown Weiss, 1997) may reflect universally low concern, an inability to resolve conflict between concerned and unconcerned states, or high concern but uncertainty about the best way to address the problem. Indeed, the nature of the solution shapes interests as much as the nature of the problem. Regimes with ecologically unambitious goals may none-the-less induce significant resistance if the regime design involves high costs or imposes costs on powerful economic sectors. Thus, the climate convention evoked considerable resistance even though its emission reduction goals fall far short of what climatologists consider necessary to prevent climate change. Regimes that seek broad or deep cooperation, provide little flexibility and involve stringent enforcement will generally be resisted, ceteris paribus, but may be adopted if states expect large benefits (Downs et al., 1996). Unfortunately, we know little about how different institutional designs, whether market incentives, financial and technological transfers, or differing legal structures, increase or retard the willingness of states to join.
Regimes may not always reflect self-conscious, voluntary cooperation (Gruber, 2000). Hegemonic states, or groups of states, can impose regimes (Young, 1989: 84-6). Most whaling states accepted the moratorium on commercial whaling only under pressure from the United States. Likewise, regimes addressing industrialized states' concerns are more likely to be negotiated quickly and implemented fully than those addressing developing states' concerns (Haas, 1992a: 221).

Yet, in environmental affairs, structural power provides less explanatory leverage than realists might have us believe (Zürn, 1998: 625). Issuespecific power, in the ability to influence outcomes if no agreement is reached as well as in voting and bargaining power within treaty regimes, gives states considerable power over what gets done, when and how. China and India refused to join the ozone regime until industrialized states codified financial transfers in formal amendments. Although lacking any formal veto, Brazil can effectively prevent progress in protecting tropical rainforests, just as Botswana, Namibia and Zimbabwe can in protecting elephants. At the same time, when the states needed to resolve a problem also share a desire to resolve it, formal regimes may prove unnecessary. Spontaneous patterns of social practice can develop to resolve problems without resort to voting, formal rules and compliance procedures (Young, 1989: 84-6).

\section{Discourses, Framing and Knowledge}

Discussing situation structure statically assumes states have 'relatively well-developed conceptions of their own interests' that they bring to, and maintain during, negotiations (Young, 1998a: 97). Yet, preferences will be less clear and stable when issues are complex, knowledge is uncertain, and material interests are 'weakly or ambiguously affected' (Stokke, 1998: 132-3). High levels of uncertainty make interests hard to identify, creating a 'veil of uncertainty' that may facilitate or hinder regime formation (Zürn, 1998: 629-30). Regime bargaining exhibits elements of rationalist, game-theoretic perspectives in which preferences, strategies and possible outcomes are 'identifiable and fixed' and of constructivist perspectives in which these features result from, rather than being inputs to, the negotiation (Zürn, 1998: 627). Words persuade as well as communicate interests, threats and promises. Evaluating rationalist and constructivist claims requires comparing precise, observable, non-trivial and competing predictions to the empirical evidence.

Science has received particular attention as a force promoting environmental cooperation. Scientific identification of the existence of, causes of and solutions to an environmental problem seems at least necessary to regime formation. Yet, even in the 
extensively studied case of ozone depletion, debate continues over whether scientific consensus was a proximate cause of the Montreal Protocol and even whether it emerged before 'the real decisions had been made' (Haas, 1992a: 224). Some argue that policy-makers delegate power to epistemic communities under conditions of unce tainty, thereby averting otherwise-debilitating conflicts of interests (Haas, 1992a: 188, 215). Others are more skeptical, noting that the values and power embedded in scientific information often rationalize or reinforce rather than reduce political conflict (Jasanoff, 1990; Litfin, 1994: 186). Scientists certainly do influence international negotiations, not least because scientists' methods and rules of discursive legitimacy are an alternative to strictly interest-based bargaining. That said, those methods and rules do not prevent bias and partiality in the arguments and facts scientists offer and even less prevent policy-makers from selectively using or ignoring science to support interest-based positions.

Discursive forces also alter perceived interests and, hence, whether and what type of regimes form. Framing a problem as 'global' gives 'every participant in the negotiation process real bargaining leverage' and veto power (Young, 1998a: 14). Framing the problem as regional may facilitate evolutionary progress, as evident in UNEP's regional seas agreements and the European regime for marine pollution enforcement whose imitation in other regions has, over time, produced an increasingly global regime.

Crucial questions now involve not whether interests, power and discourse influence whether and how regimes emerge, but how to distinguish structural, material and discursive influences and the conditions of their influence. We need more careful, rather than more, theorizing to predict when states bring fixed interests to negotiations and when they identify their interests through negotiations, when science is influential and when irrelevant, and which types of discourses facilitate, instead of hinder, agreement.

\section{Actors and Processes}

Within the constraints imposed by interests, power, discourse and knowledge, actors still can influence regime formation. Although different scholars have focused on states, epistemic communities, NGOs, domestic political constituencies and individual leaders, the similarities in their lists of how these different groups influence the negotiation processsuggests a more useful distinction based on th functions they perform (Haas, 1992b: 18; McCormick, 1999; Raustiala, 1997c). Mirroring the literature, the following discussion highlights the tasks that state and non-state actors perform that aid international regime formation. Yet, it deserves note that such actors are not always influential and may hinder as well as facilitate cooperation.

Clarifying the Problem and its Causes Those who understand environmental trends and their causes can motivate negotiators by leading them to revise their estimates of the costs of reaching, or failing to reach, agreement. If claims by other governments regarding causes and solutions are often suspect, policy-makers often seek advice from epistemic communities and NGOs perceived as more impartial (Haas, 1992b: 12; Raustiala, 1997c: 727). Indeed, many NGOs, seeking the legitimacy and influence accorded to scientists, have sought out resources and expertise to supplement traditional advocacy with impartial information provision. NGOs also provide negotiators with insight into, and influence on, various constituencies' subjective perceptions of environmental harms (Princen and Finger, 1994: 217).

Pushing for Problem Resolution At local, national and international levels, NGOs, industry trade groups and even epistemic communities lobby, promote media coverage, campaign, protest, or engage in ecosabotage to raise issue salience. By providing information on the progress of international negotiations to constituencies, environmental NGOs and corporations bring pressure to bear on negotiators to support some agreements and oppose others (Lipschutz and Conca, 1993; Lipschutz and Mayer, 1996; Wapner, 1996). Using different tactics, interest groups press state officials directly or via public pressure to take action on a given issue. Scientists, corporate representatives and environmental activists also can 'infiltrate' domestic and international levels of governance, joining national delegations and working with intergovernmental organizations (IGOs) (Haas, 1992b: 27; Raustiala, 1997c: 730). They thereby influence perceptions of the interests in and importance of an issue area. Individuals, whether representing states or non-state actors, can become 'determined champions' who promote certain proposals and stage catalytic events to prompt action at crucial junctures (Haas, 1992a: 222; Young, 1998a: 72, 188; Young and Osherenko, 1993).

Designing Policies, Facilitating Agreement and Maintaining Momentum Regime design is intimately connected with negotiation progress. The desire of each state to negotiate, sign and ratify an agreement is not independent of the terms of that agreement. Framework-protocol approaches work precisely because states are willing to accept collective decision-making that they know will lead to substantive agreement before they are willing to reach substantive agreement itself. Adding redistributive financial transfers to regulatory agreements may make potential donors more resistant but 
will attract potential recipients (Lowi, 1972). Indeed, the redistributive effects of different compliance costs regularly lead states to continue negotiating rather than accept the agreement on the table. When states view transparency as crucial, devising acceptable inspection procedures can slow, and even prevent, agreement. Decisionmaking rules, proscriptions and prescriptions, implementation provisions, and withdrawal and renegotiation clauses can all become deal-breakers.

This setting rewards those who can design proposals that balance enough competing interests to foster a final agreement. 'Deft diplomacy' is crucial to 'add and subtract issues to facilitate the bargaining process, craft the terms of negotiating texts, and broker the deals needed to achieve consensus' (Young, 1998a: 23; see also Sebenius, 1983). Although material resources are certainly helpful, high-ranking IGO officials, diplomats, bureaucrats, or NGO and corporate representatives often facilitate agreement without such resources (Young, 1998a: 23). States often table proposals themselves but, equally often, non-state actors introduce proposals directly to intergovernmental negotiating bodies or through sympathetic governments. They not only provide local knowledge that contributes to policy design at the international level but also evaluate policy proposals (Haas, 1992b: 15; McCormick, 1999: 67; Princen and Finger, 1994; Raustiala, 1997c: 727).

Particularly when exogenous forces make reaching agreement more difficult or less urgent, maintaining 'political momentum' becomes crucial (Young, 1998a: 87-8). IGOs help by providing a forum for discussion and by proposing regulative and institutional models (List and Rittberger, 1998: 70-1). States have granted NGOs (particularly, the Earth Negotiations Bulletin) access to negotiations because they want detailed and impartial daily reporting and will accept, in exchange, its public dissemination (Raustiala, 1997c: 730). NGOs and issue networks also help mobilize international opinion when agreements near completion or require ratification (Princen and Finger, 1994). Entrepreneurial leaders employ various techniques to ensure progress can be made when political conditions ripen, as evident in UNEP executive director Mostafa Tolba's proposals that fostered the ozone regime negotiations (Keohane, 1996: 26; Young, 1998a: 119).

\section{Unilateral State Action and Non-state Action}

While most arms control, trade and human rights regimes target state behavior, most environmental regimes ultimately target private actors. Scholars are increasingly highlighting efforts to protect the international environment without regimes, through state unilateralism, $\mathrm{NGO}$ action or changes in $\mathrm{MNC}$ policies. States sometimes act to protect the global environment when doing so appears materially irrational. The United States has sanctioned violations of international environmental laws, even when others harmed by those violations fail to do so (DeSombre, 2000). European states often provide bilateral assistance for environmental projects that yield few material benefits (Keohane and Levy, 1996). Such unilateralism does not imply that states act against their material interests, but that domestic environmental interests can align themselves with economic interests in ways that foster international environmental protection without regimes.

Items that fail to get the attention of states need not languish, however. Indeed, if 'states are the problem', circumventing their power may be preferred as quicker, easier and more open to innovation (Deudney, 1990). NGOs and transnational issue networks can engage in 'world civic politics', directly attempting to influence the values and behaviors of individuals and corporations (Lipschutz and Mayer, 1996; Wapner, 1996). NGOs can use rhetorical persuasion, rather than coopting the coercive power of the state, to target places where state control is weak, outcomes are less predetermined, and behavior is more 'amenable to alternative practices' (Wapner, 1996: 156-60).

NGOs regularly operate projects directly with local communities without significant governmental or intergovernmental involvement (McCormick, 1999: 66). NGOs acquire and protect ecosystems directly and through debt-for-nature swaps (Jakobeit, 1996). NGOs prompt consumer boycotts and 'buy green' campaigns that directly shape corporate incentives (Wapner, 1996). Direct NGO pressure, more diffuse pressure from an increasingly 'green' market and the personal values of employees all contribute to domestic corporations, MNCs and trade organizations including environmental concerns in the production calculus (Garcia-Johnson, 2000). The Forest Stewardship Council, International Organization for Standardization (ISO), and other groups that include corporate representatives, NGOs or both, have developed ecolabeling schemes and voluntary codes of conduct that skirt government regulation and provide information directly to consumers (Clapp, 1998). NGOs and industry are rarely averse to, and often are observed, working with governments on programs such as these, but increasingly proceed with them when government cooperation is absent.

\section{Policy Implementation AND EFFeCTIVENESS}

Ultimately, the value of formulating new interstate, state and non-state policies depends on whether they alter human behaviors in ways that 
improve the environment. Promulgating good policy requires understanding which policies are most likely to be implemented in ways that will produce desired behavioral changes and environmental benefits. Even more than policy formulation, work on policy implementation and effectiveness in international environmental affairs has been dominated by the study of regimes. During the 1990s, individuals and teams representing differing disciplines, countries and theoretical approaches examined numerous cases to produce a remarkably coherent research program. Just English-language edited volumes directly evaluating environmental regime effectiveness identify a plethora of factors and forces considered influential (Andresen and Wettestad, 1995; Brown Weiss and Jacobson, 1998; Cameron et al., 1996; Haas, et al., 1993; Hanf and Underdal, 2000; Keohane and Levy, 1996; Miles and Underdal, 2001; Victor et al., 1998; Young, 1999a; Zürn, 1998: 619 n. 4).

\section{Defining the Dependent Variables}

Agreement about what constitutes successful regime formation (states negotiating an agreement) is not matched by agreement about what constitutes policy effectiveness. To determine how much movement toward some goal a policy induced involves three tasks: identifying an appropriate goal, an appropriate metric of movement and an appropriate indicator of the share of that movement to attribute to the policy.

Identifying an appropriate goal for evaluating regime 'effectiveness' proves problematic because regimes can have so many effects, from the direct, immediate and intentional to the indirect, distant and perverse. Scholars have usefully distinguished implementation and compliance (or behavioral change) from environmental (or problem-solving) effectiveness (Brown Weiss and Jacobson, 1998; Peterson, 1998; Underdal, 2001: 4; Victor et al., 1998). We can start with the last of these, asking 'how well did this regime resolve the problem that led to its formation' (Bernauer, 1995: 366; Young, 1999b: 109). Thus, agreed-upon goals in a treaty's preamble or elsewhere become an appropriate metric. However, participants often establish regimes without agreement on objectives or change their objectives over time (Young, 1999b: 109). Indeed, much hard law and most non-binding soft law involves vague or ambiguous language that makes identifying a goal against which to evaluate performance almost impossible.

Equally important, analysts may want to evaluate progress toward goals other than those held by the parties involved (Helm and Sprinz, 1999; Underdal, 2001). Thus, the nominal goal of the whaling convention is 'to provide for the proper conservation of whale stocks and thus make possible the orderly development of the whaling industry', but we may want to know how it has contributed to promoting a norm of a whales' right to life (D'Amato and Chopra, 1991). Indeed, analysts have begun trying to identify 'collective optima', that is, what full environmental protection would have required, as an additional metric of environmental effectiveness (Underdal, 2001).

Second, an interest in environmental improvement quickly shifts when we recognize that achieving that goal requires human behavior change. Equally important, environmental regimes generally target behavioral changes at state and sub-state levels, in a post-negotiation two-level game (Putnam, 1988). Regime effects are evident in implementation - laws, regulations and governmental use of sanctions, rewards and other policies and in behavior changes by the ultimate targets of the regime. For the latter, legal compliance is a useful, and usually readily available, metric but misses 'overcompliance' and 'good faith non-compliance' that also constitute evidence of regime influence (Mitchell, 1996). For example, the influence of the LRTAP convention was more evident in the otherwise-unlikely 10 per cent reductions in Hungarian sulfur emissions than from reductions by many other countries that far surpassed the 30 per cent requirement (Levy, 1993). The problem, of course, with using behavior is that regimes may induce significant behavioral change that falls far short of the environmental goals established by regime negotiators, let alone scientists or environmental advocates.

Finally, regime efficiency, cost-effectiveness and equity have yet to receive much analytic attention (Bernauer, 1995: 358; Brown Weiss, 1989). Although some scholars have sought to promote one metric or definition of effectiveness as superior to others, progress requires that the research community, even if not individual scholars, adopt an inclusive set of definitions so we can assess how even a single regime varies across various dimensions of effectiveness. The choice of which dimension to evaluate will reflect different analytic goals and normative preferences, making it futile and potentially counterproductive to give one primacy over another. And, in any event, a broad approach will be crucial to evaluating the many regimes with multiple, ambiguous, implicit, or misleading goals and with effects that are less intended and more farranging than usually assumed.

Beyond identifying a goal for evaluation, the analyst must identify a criterion of effectiveness. Two basic categories of criteria have been identified: relative improvement and goal achievement (Underdal, 2001: 5). The first compares the observed value of some effectiveness parameter to a no-regime baseline. The second compares that observed value to the desired value of that parameter, as defined by regime negotiators ('goal achievement') or an independent analyst 
('collective optimum') (Underdal, 2001: 6). These standards are complementary, with the former 'glass half full' criteria asking how far have we come and the second 'glass half empty' criteria asking how far have we yet to go. Helm and Sprinz have proposed a metric that combines these criteria, involving actual performance relative to a no-regime baseline expressed as a fraction of total possible improvement relative to that same baseline (Helm and Sprinz, 1999). This provides a valuable first step toward transcending claims that a regime 'made a difference' to evaluating how much of a regime's 'potential' was realized and allowing comparison of relative effectiveness across regimes.

All efforts to identify the influence of a regime require comparison of observed outcomes to a carefully hypothesized counterfactual state of affairs in the absence of the regime. Indeed, the literature's focus on behaviors, enforcement, imple mentation and compliance rather than environmental improvement does not reflect a lack of environmental concern but that our skill in estimating counterfactuals of environmental resource quality (a product of natural variation, human behavior, and myriad other factors) is even more limited than in estimating human behavior (Brown Weiss and Jacobson, 1998; Miles and Underdal, 2001; Victor et al., 1998; Young, 1999a). Behavioral change provides a useful but limited proxy for regime effects: regimes that cause no behavior change are certainly ineffective in behavioral and environmental terms; those that cause some behavior change are behaviorally effective but may none the less be environmentally ineffective (Underdal, 2001: 4). Thus, whether by counterfactuals, contrasting cases, or process tracing, the goal is to distinguish regime influences from the myriad other influences on human behavior or the environment.

Several additional aspects of regime effectiveness research deserve comment. Work has only begun to evaluate how success varies over a regime's life cycle (Gehring, 1994). Likewise, research to date has focused on absolute effectiveness, that is, 'do regimes matter', a question answerable through single case studies. Research on relative effectiveness that compares one regime to another is crucial but must surmount obstacles such as whether the regimes being compared addressed similar problems, were at similar stages in their life cycle and held other determinants of effectiveness constant (Underdal, 2001: 13-14; Young, 1999b: 114). Some, but still not enough, research has begun to move away from 'sterile debates' about whether regimes influence behavior toward policy-relevant identification of the features and conditions that help regimes perform better (see also Bernauer, 1995: 374; Underdal, 2001: 8; Young, 1999b: 116).

\section{Structural Forces and Constraints}

Building on Brown Weiss and Jacobson, I categorize regime effectiveness as dependent on characteristics of the issue area, the international setting, the targeted actor and the regime (Brown Weiss and Jacobson, 1998: 535-42). The first three can be considered as structural forces that establish a range of potential influence in which regime design then determines outcomes (Young, 1999a: 124).

Issue Area An issue area's structure influences a regime's effectiveness by shaping how willing and able targeted actors, whether states or non-state actors, are to alter their behavior. Regimes must manipulate these 'baseline' incentives and abilities to induce actors otherwise inclined to behave contrary to regime goals to align their behavior with regime goals and rules (Miles and Underdal, 2001). A regime's ability to alter behavior depends on how the incentives and abilities to engage in existing behaviors match those for desired new behaviors (Hasenclever et al., 1997: 62ff.; Martin, 1992b; Underdal, 2000: 1; Victor et al., 1998; Young, 1999b: 117). Situation structure shapes the types of problems a regime will face. Prisoner's dilemma type problems will encourage clandestine cheating while offering rewards to upstream states to induce reduced pollution may prompt public declarations of non-compliance to extract greater rewards. Those who are more ecologically vulnerable will tend to outperform those who are less (Sprinz and Vaahtoranta, 1994). Those for whom change is costly will be more recalcitrant than those for whom it is cheap. Problems whose resolution requires new behaviors will face violations due to incentives and incapacity while regimes that require only restraint will face only those due to incentives.

Material sources of interests are intertwined with how relevant actors define and perceive the environmental problem. Whether poor environmental quality translates into high environmental concern and behavior change depends on where environmental protection fits in a state or non-state actor's value system and on broader domestic and international norms regarding the importance of environmental protection. Certainly, actors will ignore a regime's dictates when they have strong, immediate and clear material interests in doing so. But the values held by individuals, civil society, epistemic communities, NGOs and MNCs wield considerable influence over their own responses and those of the states they compose.

Overlaying power onto the pattern of interests provides additional insight into patterns of regime effectiveness. Powerful states that have independent incentives to meet their commitments often attempt to reassure more cautious states enough to induce them also to cooperate (Chayes and Chayes, 1995). Likewise, powerful states that oppose a 
regime can induce less adherence by states that might otherwise have changed their behaviors. Other issue-specific factors also influence behavioral incentives, including the number of other actors involved, levels of uncertainty about the science of the problem or its resolution, the inherent transparency of relevant behaviors, the role and position of MNCs and the concentration of the activity being regulated (Brown Weiss and Jacobson, 1998: Figure 15.2, p. 536).

Actor Characteristics The responses of states and sub-state actors also vary within and across regimes because of actor-level traits. Variation in beliefs, interests and capacities that are independent of the issue area will produce different levels of commitment to a regime. Countries vary in their levels of domestic environmental concern, government efficiency and effectiveness in responding to those concerns, and political and administrative capacity to implement international commitments (Haas et al., 1993). Brown Weiss and Jacobson attribute variation in compliance levels to national characteristics ranging from previous behavior, history and physical size to number of neighbors, type of economy and institutions, and level of knowledge (Brown Weiss and Jacobson, 1998). Others focus on support from corporate and private actors for regime goals and the means chosen to implement regime rules (Hanf and Underdal, 2000; Raustiala, 1997a; Underdal, 1998; Young, 1998a: 142-54). Such support, in turn, depends on the power and participation of regulated and countervailing groups, economic forces and market conditions, political environmental mobilization and the strength of regulatory and administrative structures (Raustiala and Victor, 1998).

Variation in the capacity to implement regimes also influences their success. Some environmental agreements involve positive commitments requiring large expenditures or developing new technologies while others involve negative commitments requiring only that actors refrain from certain actions. In most regimes, the distribution of burdens is likely to mean at least some actors are financially, technically or administratively incapable of complying. Although claims of incapacity often will mask a lack of incentives to comply, violations often can truly stem from incapacity.

International Context A regime's capacity to alter actors' behaviors also depends on the broader international context (Brown Weiss and Jacobson, 1998; Young, 1999b: 123). Regimes have an easier task when their goals align with the current intellectual order and forms of discourse (such as economic integration and political liberalization), the frequency and visibility of major international environmental conferences, the number and strength of environmental NGOs and the attention being given to environmental issues generally (Brown Weiss and Jacobson, 1998: 536; Victor et al., 1998; Young, 1992). Since these factors enhance or inhibit a regime's ability to influence behavior, they also serve as important alternative explanations of a regime's effectiveness.

\section{Regime Design}

Were realist theory always correct, then characteristics of the issue area, actors and international context would determine behavioral outcomes. Institutionalists have shown, however, that regime design and 'problem-solving capacity' also influence outcomes (Mitchell, 1994b; Underdal, 2001: 1). What follows attempts to make sense of the 'plethora of propositions as to which types of institutions are likely to be more effective' (Bernauer, 1995: 374).

The social and political process of defining what problem a regime will address and what strategies and how aggressively to address it determine effectiveness by defining the regime's goal, how hard and costly it will be to achieve, and how much resistance there will be to achieving it. Aggressive goals may motivate significant behavior change by those who try yet fail to meet them, or may be ignored as unachievable. More realistic goals may achieve visible results quickly, but may provide few incentives for actors to do more. At this stage, both theoretical and empirical work on the goals behavior link is needed.

The means of goal achievement also surely matters. Yet, simple questions of whether binding regulations induce more change than non-binding ones remain open (Brown Weiss, 1997). Clear regulatory rules may seem crucial to behavioral change, but we do not yet know whether such regimes induce more or less behavior change than procedural regimes that facilitate recurring collective choice, programmatic regimes that pool resources toward collective goals, or generative regimes that foster development of new norms and social practices (Young, 1998a: 145; Young, 1999b: 24ff.). The conditions for success of regulatory regimes have been more fully specified, however (if only because their explicitness makes measuring effectiveness easier), providing the foundation for what follows.

Regulatory regimes induce compliance through their primary rule system, compliance information system and non-compliance response system (Mitchell, 1996). Effective regimes design these systems so that they respond to or 'fit' the environmental and behavioral demands of the problem they address. For any given problem, regime designers must choose among behavioral prescriptions and proscriptions. When these primary rules can apply to different actors, deciding which activity to regulate dictates which actors with what interests and 
capacities must change their behavior, how large and costly those changes will be, and whether other factors will reinforce or undercut compliance incentives. Designing more specific rules clarifies what is expected for those predisposed to comply and removes the opportunity to claim inadvertence or misinterpretation for those predisposed to violate. Even the perception that the rules were generated and implemented in equitable and reasonable ways can influence the willingness to change behavior (Brown Weiss and Jacobson, 1998; Victor et al., 1993: 468-71). Regulating highly visible or transparent activities or those that involve transactions between actors can reassure each actor that others are complying and allow them to protect their interests if they are not.

A regime can further increase transparency through design of the compliance information system. Whether regimes include reciprocity, sanctions, or rewards, altering behavior requires that actors know their behaviors will be noticed. Although most regimes rely on self-reporting, systems that supply incentives and build the capacity to report work better than others that sanction non-reporting or fail to address practical obstacles to reporting (Mitchell, 1998). Intrusive monitoring systems have been authorized in several environmental agreements and rising environmental concern may make them more common. Regimes can also increase transparency by rewarding compliance only if actors also supply reports or allow inspections.

Beyond clear rules, transparency and other such features, a regime's influence depends on how it responds to those who comply and those who do not. The direct tit-for-tat that can discourage violations of economic and arms control agreements proves less useful in environmental realms where regime supporters are unwilling to harm the environment as a retaliatory sanction and, even if they did, would not influence those unconcerned about the environment. Recognizing this, many scholars and practitioners stress the need for treaties to couple economic sanctions with careful monitoring and verification mechanisms to trigger them (Bernauer, 1995: 363; Downs et al., 1996; Wettestad, 1995). In a seminal piece, Chayes and Chayes (1995) argued that such an enforcement model was less effective than a more 'managerial' approach, employing diplomacy, norms and rewards. Rewards can induce actors, especially unconcerned 'upstream' actors, to alter their behavior (Bernauer, 1995: 371). Theoretical debate and empirical research continues to attempt to determine whether sanctions are always needed or needed only for 'deep' cooperation, and under what conditions, if any, rewards may prove more effective (Downs et al., 1996; Underdal, 2001: 13).

Beyond sanctions and rewards, 'systems of implementation review' and 'sunshine methods' involving reporting, monitoring and review may induce compliance even without explicit and direct responses (Brown Weiss and Jacobson, 1998; Victor et al., 1998). Ecolabeling, certification and prior informed consent rules may induce behavioral changes via marketplace incentives (Krueger, 1999). Norms, argument and persuasion can influence behavior by altering notions of appropriate and inappropriate action (Finnemore, 1996). Thus, the wetland treaty's vague norm to make 'wise use' of wetlands has prompted ongoing discussions about what wise use means, slowly altering traditional perceptions that wetlands are wastelands. The difficulty of demonstrating the influence of norms should not lead us to disregard their potential importance. Crucial questions remain regarding which of various strategies work best in which circumstances, controlling for characteristics of the issue area, international context and actors.

Finally, regime design involves attention to those who support implementation. The material and intellectual power, resources and expertise of the secretariat, other international organizations and supportive NGOs can contribute significantly to implementation (List and Rittberger, 1998: 72; Peterson, 1998; Ringius, 1997; Sandford, 1996). Even MNCs can aid implementation, as when major chemical corporations hastened the phase-out of CFCs because, fearing international regulation, they developed alternatives that were cheaper.

\section{Policy Evolution and Social Learning}

Evolution and learning constitute something like a fifth policy stage facilitating revision and improvement in the other stages. Policy change may involve simple repetition of the policy process under changed circumstances. New environmental problems may develop and be identified, move onto the international agenda, be addressed through a transnational or international policy process, and be implemented through new mechanisms. When such changes result from changes in exogenous factors, they may deserve our attention but, conceptually, involve simply new instances of these policy processes.

Recent scholarship has begun to investigate the more self-conscious process of how human societies and institutions 'get better' at global environmental management (Clark et al., 2001). How do international institutions and processes improve what we know about the environment, human impacts on the environment and our ability to reduce those impacts? These meta-questions are complex and crucial, requiring understanding 'how discoveries, experience, and innovations present in one part of the [global environmental] management system spread to others' (Clark et al., 2001: 6). 
Institutions and society can spiral rather than cycle through policy stages, becoming increasingly proficient at managing human - environment interactions (Haas and Haas, 1995).

Especially in environmental affairs, a crucial but understudied question is how to alter behavior through complex, double-loop learning that alters underlying goals rather than single-loop learning that simply alters preferences across strategies (Parson and Clark, 1995). Regimes and intergovernmental organizations can evolve dynamically, identifying 'new and sharpened rules, stricter standards and improved procedures' (see also Gehring, 1994; List and Rittberger, 1998: 76). Yet questions such as whether framework-protocol approaches work better than alternatives, why some regimes develop progressive regulatory structures and how non-state actors foster social learning remain only vaguely understood.

\section{Conclusion}

The study of international environmental politics parallels policy efforts to improve global environmental management. Scholars have generated theories and cases demonstrating why global environmental problems are so common; how they get raised to the international agenda; why states form regimes for some but not others; what factors facilitate regime effectiveness; and how evolution and learning occur. Structural forces and agents' choices wield different amounts and types of influence at different policy stages. Non-state actors wield different, and perhaps more, influence earlier in the process. Conscious social engineering appears able to resolve problems of policy formulation and implementation more than agenda-setting.

Given the many important questions still unaddressed in IEP, progress will require new and concerted efforts. Theoretically, we need a framework to make sense, for each stage of the policy process, of which factors are influential under a wide range of circumstances, which are influential only in limited circumstances, and which are simply not influential despite earlier theorizing. Methodologically, we need to supplement the almost-exclusive use of case studies with quantitative methods, formal modeling and simulation. Substantively, we need to examine more than the ozone depletion, climate change and acid rain cases that have been the empirical testbeds for too many theories. Empirically, we need to develop data for qualitative and large- $N$ quantitative comparisons across issues (Breitmeier et al., 1996; Haas and Sundgren, 1993). These efforts have begun but opportunities abound for scholars to move the sub-field forward.

If scholars of IEP are to contribute to global environmental management, we must begin developing contingent knowledge that identifies how the choices actors make promote environmental protection, the structural constraints on their ability to do so, and the conditions under which the former can help us overcome the latter.

\section{Notes}

This chapter has benefited from the criticism and suggestions of Walter Carlsnaes, Peter Haas, David Patel, M.J. Peterson, Kal Raustiala, Thomas Risse, Beth Simmons, Detlef Sprinz, Paul Steinberg, Paul Wapner, Oran Young and a particularly insightful anonymous reviewer. Generous research support was provided by the University of Oregon's Department of Political Science and Stanford University's Center for Environmental Science and Policy.

\section{Bibliography}

Andresen, Steinar and Wettestad, Jørgen (1995) 'International Problem-Solving Effectiveness: The Oslo Project Story So Far', International Environmental Affairs, 7 (2): 127-49.

Barkin, J. Samuel and Shambaugh, George (eds) (1999) Anarchy and the Environment: The International Relations of Common Pool Resources. Albany: State University of New York Press.

Barrett, Scott (1994) 'Self-enforcing International Environmental Agreements', Oxford Economic Papers, 46 (Special Issue): 878-93.

Bernauer, Thomas (1995) 'The Effect of International Environmental Institutions: How We Might Learn More', International Organization, 49 (2): 351-77.

Birnie, Patricia W. and Boyle, Alan E. (1992) International Law and the Environment. Oxford: Oxford University Press.

Boehmer-Christiansen, Sonja A. and Skea, James (1991) Acid Politics: Environmental and Energy Policies in Britain and Germany. London: Belhaven Press.

Breitmeier, Helmut, Levy, Marc A., Young, Oran R. and Zürn, Michael (1996) 'The International Regimes Database as a Tool for the Study of International Cooperation', WP-96-160. Laxenburg, Austria: International Institute for Applied Systems Analysis.

Brown Weiss, Edith (1989) In Fairness to Future Generations: International Law, Common Patrimony, and Intergenerational Equity. Dobbs Ferry, NY: Transnational Publishers.

Brown Weiss, Edith (ed.) (1997) International Compliance with Nonbinding Accords. Washington, DC: American Society of International Law.

Brown Weiss, Edith and Jacobson, Harold K. (eds) (1998) Engaging Countries: Strengthening Compliance with International Environmental Accords. Cambridge, MA: MIT Press.

Caldwell, Lynton Keith (1984) International Environmental Policy. Durham, NC: Duke University Press. 
Cameron, James, Werksman, Jacob and Roderick, Peter (eds) (1996) Improving Compliance with International Environmental Law. London: Earthscan.

Chayes, Abram and Chayes, Antonia Handler (1995) The New Sovereignty: Compliance with International Regulatory Agreements. Cambridge, MA: Harvard University Press.

Choucri, Nazli (ed.) (1993) Global Accord: Environmental Challenges and International Responses. Cambridge, MA: MIT Press.

Clapp, Jennifer (1998) 'The Privatization of Global Environmental Governance: ISO 14000 and the Developing World', Global Governance, 4 (3): 295-316.

Clark, William C., Dickson, Nancy M., van Eijndhoven, Josee and Jäger Jill (eds) (2001) Learning to Manage Global Environmental Risks: A Comparative History of Social Responses to Climate Change, Ozone Depletion, and Acid Rain. Cambridge: MIT Press.

Conca, Ken (1994) 'Rethinking the Ecology-Sovereignty Debate', Millennium, 23 (3): 1-11.

Conca, Ken, Alberty, Michael and Dabelko, Geoffrey (eds) (1996) Green Planet Blues. Boulder: Westview.

Connolly, Barbara (1996) 'Increments for the Earth: The Politics of Environmental Aid', in Robert O. Keohane and Marc A. Levy (eds), Institutions for Environmental Aid: Pitfalls and Promise. Cambridge, MA: MIT Press. pp. 327-65.

Corell, Elisabeth (1999) 'The Negotiable Desert: Expert Knowledge in the Negotiations of the Convention to Combat Desertification', PhD dissertation, Linkoping University, Linkoping, Sweden.

D’Amato, Anthony and Chopra, Sudhir K. (1991) 'Whales: Their Emerging Right to Life', American Journal of International Law, 85 (1): 21-62.

Dauvergne, Peter (1997) Shadows in the Forest: Japan and the Politics of Timber in Southeast Asia. Cambridge, MA: MIT Press.

Dawson, Jane (1996) Eco-Nationalism. Durham, NC: Duke University Press.

DeSombre, Elizabeth R. (2000) Domestic Sources of International Environmental Policy: Industry, Environmentalists, and US Power. Cambridge, MA: MIT Press.

Dessler, David (1989) 'What's at Stake in the AgentStructure Debate?', International Organization, 43 (3): 441-73.

Deudney, Daniel (1990) 'The Case Against Linking Environmental Degradation and National Security', Millennium, 19 (3): 461-76.

Devall, Bill and Sessions, George (1985) Deep Ecology. Salt Lake City: Peregrine Smith Books.

Downs, George W., Rocke, David M. and Barsoom, Peter N. (1996) 'Is the Good News about Compliance Good News about Cooperation?', International Organization, 50 (3): 379-406.

Falk, Richard (1971) This Endangered Planet: Prospects and Proposals for Human Survival. New York: Vintage.

Finnemore, Martha (1996) National Interests in International Society. Ithaca: Cornell University Press.
Garcia-Johnson, Ronie (2000) Exporting Environmentalism: US Multinational Chemical Corporations in Brazil and Mexico. Cambridge, MA: MIT Press.

Gehring, Thomas (1994) Dynamic International Regimes: Institutions for International Environmental Governance. Frankfurt-am-Main: P. Lang.

Gruber, Lloyd (2000) Ruling the World. Princeton: Princeton University Press.

Haas, Peter M. (1989) 'Do Regimes Matter? Epistemic Communities and Mediterranean Pollution Control', International Organization, 43 (3): 377-403.

Haas, Peter M. (1990) Saving the Mediterranean: The Politics of International Environmental Cooperation. New York: Columbia University Press.

Haas, Peter M. (1992a) 'Banning Chlorofluorocarbons', International Organization, 46 (1): 187-224.

Haas, Peter M. (1992b) 'Epistemic Communities and International Policy Coordination', International Organization, 46 (1): 1-35.

Haas, Peter M. and Haas, Ernst B. (1995) 'Learning to Learn: Improving International Governance', Global Governance, 1 (3): 255-85.

Haas, Peter and Sundgren, Jan (1993) 'Evolving International Environmental Law: Changing Practices of National Sovereignty', in Nazli Choucri (ed.), Global Accord: Environmental Challenges and International Responses. Cambridge, MA: MIT Press. pp. 401-29.

Haas, Peter M., Keohane, Robert O. and Levy, Marc A. (eds) (1993) Institutions for the Earth: Sources of Effective International Environmental Protection. Cambridge, MA: The MIT Press.

Hardin, Garrett (1968) 'The Tragedy of the Commons', Science, 162 (3859): 1243-8.

Hasenclever, Andreas, Mayer, Peter and Rittberger, Volker (1997) Theories of International Regimes. Cambridge: Cambridge University Press.

Helm, Carsten and Sprinz, Detlef (1999) 'Measuring the Effectiveness of International Environmental Regimes', 52. Potsdam: Potsdam Institute for Climate Impact Research.

Hurrell, Andrew and Kingsbury, Benedict (eds) (1992) The International Politics of the Environment: Actors, Interests, and Institutions. Oxford: Oxford University Press.

Inglehart, Ronald (1995) 'Public Support for Environmental Protection: The Impact of Objective Problems and Subjective Values in 43 Societies', Political Science and Politics, 27 (1): 57-71.

Jakobeit, Cord (1996) 'Nonstate Actors Leading the Way: Debt-for-Nature Swaps', in Robert O. Keohane and Marc A. Levy (eds), Institutions for Environmental Aid: Pitfalls and Promise. Cambridge, MA: MIT Press. pp. 127-66.

Jasanoff, Sheila (1986) Risk Management and Political Culture: A Comparative Study of Science in the Policy Context. New York: Russell Sage Foundation.

Jasanoff, Sheila (1990) The Fifth Branch: Science Advisers as Policymakers. Cambridge, MA: Harvard University Press.

Kammen, Daniel M. and Dove, Michael R. (1997) 'The Virtues of Mundane Science', Environment, 39 (6): 10-9. 
Kay, David A. and Jacobson, Harold K. (eds) (1983) Environmental Protection: The International Dimension. Totowa: Allanheld, Osmun \& Co.

Keohane, Robert O. (1996) 'Analyzing the Effectiveness of International Environmental Institutions', in Robert O. Keohane, and Marc A. Levy (eds), Institutions for Environmental Aid: Pitfalls and Promise. Cambridge, MA: MIT Press. pp. 3-27.

Keohane, Robert O. and Levy, Marc A. (eds) (1996) Institutions for Environmental Aid: Pitfalls and Promise. Cambridge, MA: MIT Press.

Krueger, Jonathan (1999) International Trade and the Basel Convention. London: Royal Institute of International Affairs.

Levy, Marc (1993) 'European Acid Rain: The Power of Tote-Board Diplomacy', in Peter Haas, Robert O. Keohane and Marc Levy (eds), Institutions for the Earth: Sources of Effective International Environmental Protection. Cambridge, MA: MIT Press. pp. 75-132.

Lipschutz, Ronnie D. and Conca, Ken (eds) (1993) The State and Social Power in Global Environmental Politics. New York: Columbia University Press.

Lipschutz, Ronnie D. and Mayer, Judith (1996) Global Civil Society and Global Environmental Governance: The Politics of Nature From Place to Planet. Albany: State University of New York.

List, Martin and Rittberger, Volker (1998) 'The Role of Intergovernmental Organizations in the Formation and Evolution of International Environmental Regimes', in Arild Underdal (ed.), The Politics of International Environmental Management. Dordrecht: Kluwer Academic Publishers. pp. 67-81.

Litfin, Karen T. (1994) Ozone Discourses: Science and Politics in Global Environmental Cooperation. New York: Columbia University Press.

Litfin, Karen T. (ed.) (1998) The Greening of Sovereignty in World Politics. Cambridge, MA: MIT Press.

Lowi, Theodore J. (1972) 'Four Systems of Policy, Politics, and Choice', Public Administration Review, 32 (4): 298-310.

Malthus, T.R. and Appleman, Philip (1976) An Essay on the Principle of Population: Text, Sources and Background, Criticism. New York: W.W. Norton.

Martin, Lisa L. (1992a) Coercive Cooperation: Explaining Multilateral Economic Sanctions. Princeton: Princeton University Press.

Martin, Lisa L. (1992b) 'Interests, Power, and Multilateralism', International Organization, 46 (4): 765-92.

McCormick, John (1999) 'The Role of Environmental NGOs in International Regimes', in Norman J. Vig and Regina S. Axelrod (eds), The Global Environment: Institutions, Law, and Policy. Washington, DC: CQ Press. pp. 52-71.

Merchant, Carolyn (1996) Earthcare: Women and the Environment. New York: Routledge.

Meyer, John W., Frank, David John, Hironaka, Ann, Schofer, Evan and Tuma, Nancy Brandon (1997) 'The Structuring of a World Environmental Regime, 1870-1990', International Organization, 51 (4): 623-9.
M'Gonigle, R. Michael and Zacher, Mark W. (1979) Pollution, Politics, and International Law: Tankers at Sea. Berkeley, CA: University of California Press.

Miles, Edward L. and Underdal, Arild (eds) (2001) Explaining Environmental Regime Effectiveness: Confronting Theory with Evidence. Cambridge, MA: The MIT Press.

Miller, Marian A.L. (1995) The Third World in Global Environmental Politics. Boulder: Lynne Rienner.

Mitchell, Ronald B. (1994a) Intentional Oil Pollution at Sea: Environmental Policy and Treaty Compliance. Cambridge, MA: The MIT Press.

Mitchell, Ronald B. (1994b) 'Regime Design Matters: Intentional Oil Pollution and Treaty Compliance', International Organization, 48 (3): 425-58.

Mitchell, Ronald B. (1996) 'Compliance Theory: An Overview', in James, Cameron Jacob Werksman and Peter Roderick (eds), Improving Compliance with International Environmental Law. London: Earthscan. pp. 3-28.

Mitchell, Ronald B. (1998) 'Sources of Transparency: Information Systems in International Regimes', International Studies Quarterly, 42 (1): 109-30.

Mitchell, Ronald B. and Bernauer, Thomas (1998) 'Empirical Research on International Environmental Policy: Designing Qualitative Case Studies', Journal of Environment and Development, 7 (1): 4-31.

Mitchell, Ronald B. and Keilbach, Patricia (2001) 'Reciprocity, Coercion, or Exchange: Symmetry, Asymmetry and Power in Institutional Design', International Organization, 55 (4).

Naess, Arne (1973) 'The Shallow and the Deep, LongRange Ecology Movement: A Summary', Inquiry, 16 (1): 95-100.

O'Neill, Kate (2000) Waste Trading Among Rich Nations. Cambridge, MA: The MIT Press.

Ophuls, William (1977) Ecology and the Politics of Scarcity: Prologue to a Political Theory of the Steady State. San Francisco: W.H. Freeman.

Orr, David W. and Soroos, Marvin S. (eds) (1979) The Global Predicament: Ecological Perspectives on World Order. Chapel Hill: University of North Carolina Press.

Parson, Edward A. and Clark, William C. (1995) 'Sustainable Development as Social Learning: Theoretical Perspectives and Practical Challenges for the Design of a Research Program', in Lance Gunderson, C.S. Holling and Stephen S. Light (eds), Barriers and Bridges to the Renewal of Ecosystems and Institutions. New York: Columbia University Press.

Peterson, M.J. (1998) 'International Organizations and the Implementation of Environmental Regimes', in Oran R. Young (ed.), Global Governance: Drawing Insights from the Environmental Experience. Cambridge, MA: MIT Press. pp. 115-51.

Porter, Gareth and Brown, Janet Welsh (1991) Global Environmental Politics. Boulder: Westview.

Princen, Thomas (1996) 'The Zero Option and Ecological Rationality in International Environmental Politics', International Environmental Affairs, 8 (2): 147-76. 
Princen, Thomas and Finger, Matthias (1994) Environmental NGOS in World Politics: Linking the Local and the Global. New York: Routledge.

Putnam, Robert D. (1988) 'Diplomacy and Domestic Politics: The Logic of Two-Level Games', International Organization, 42 (3): 427-60.

Raustiala, Kal (1997a) 'Domestic Institutions and International Regulatory Cooperation: Comparative Responses to the Convention on Biological Diversity', World Politics, 49 (4): 482-509.

Raustiala, Kal (1997b) 'The Domestic Politics of Global Biodiversity Protection in the United Kingdom and the United States', in Miranda A. Schreurs and Elizabeth Economy (eds), The Internationalization of Environmental Protection. Oxford: Oxford University Press. pp. 42-73.

Raustiala, Kal (1997c) 'States, NGOs, and International Environmental Institutions', International Studies Quarterly, 41 (4): 719-40.

Raustiala, Kal and Victor, David G. (1998) 'Conclusions', in David G. Victor, Kal Raustiala and Eugene B. Skolnikoff (eds), The Implementation and Effectiveness of International Environmental Commitments: Theory and Practice. Cambridge, MA: The MIT Press. pp. 659-707.

Ringius, Lasse (1997) 'Environmental NGOs and Regime Change: The Case of Ocean Dumping of Radioactive Waste', European Journal of International Relations, 3 (1): 61-104.

Risse, Thomas (2001) 'Transnational politics and nonstate actors', in Walter Carlsnaes, Thomas Risse and Beth Simmons (eds), Handbook of International Relations. London: Sage.

Rosenau, James N. (1993) 'Environmental Challenges in a Global Context', in Sheldon Kamieniecki (ed.), Environmental Politics in the International Arena. Albany: State University of New York Press. pp. 257-74.

Ruggie, John Gerard (1975) 'International Responses to Technology: Concepts and Trends', International Organization, 29 (3): 557-83.

Ruggie, John Gerard (1998) 'What Makes the World Hang Together? Neo-Utilitarianism and the Social Constructivist Challenge', International Organization, 52 (4): 855-85.

Sandford, Rosemary (1996) 'International Environmental Treaty Secretariats: A Case of Neglected Potential?', Environmental Impact Assessment Review, 16 (1): 3.

Sands, Philippe (ed.) (1994) Greening International Law. New York: The New Press.

Schreurs, Miranda A. and Economy, Elizabeth (eds) (1997) The Internationalization of Environmental Protection. Oxford: Oxford University Press.

Sebenius, James K. (1983) 'Negotiation Arithmetic: Adding and Subtracting Issues and Parties', International Organization, 37 (2): 281-316.

Shea, Eileen (ed.) (1997) A Critical Evaluation of Global Environmental Assessments: The Climate Experience. Boulder: Center for the Application of Research on the Environment.
Soroos, Marvin S. (1999) 'Global Institutions and the Environment: An Evolutionary Perspective', in Norman J. Vig and Regina S. Axelrod (eds), The Global Environment: Institutions, Law and Policy. Washington, DC: CQ Press. pp. 27-51.

Sprinz, Detlef and Vaahtoranta, Tapani (1994) 'The Interest-Based Explanation of International Environmental Policy', International Organization, 48 (1): 77-105.

Sprout, Harold Hance and Sprout, Margaret Tuttle (1971) Toward a Politics of the Planet Earth. New York: Van Nostrand Reinhold.

Stokke, Olav Schram (1998) 'Understanding the Formation of International Environmental Regimes: The Discursive Challenge', in Arild Underdal (ed.), The Politics of International Environmental Management. Dordrecht: Kluwer Academic. pp. 129-48.

Swanson, Timothy M. and Johnston, Sam (1999) Global Environmental Problems and International Environmental Agreements: The Economics of International Institution Building. Cheltenham: Edward Elgar.

Underdal, Arild (ed.) (1998) The Politics of International Environmental Management. Dordrecht: Kluwer Academic.

Underdal, Arild (2001) 'One Question, Two Answers', in Edward L. Miles and Arild Underdal (eds), Explaining Environmental Regime Effectiveness: Confronting Theory with Evidence. Cambridge, MA: The MIT Press. pp. 1-47.

Underdal, Arild and Hanf, Kenneth (eds) (2000) International Environmental Agreements and Domestic Politics: The Case of Acid Rain. Aldershot: Ashgate.

Victor, David G., Chayes, Abram and Skolnikoff, Eugene B. (1993) 'Pragmatic Approaches to Regime Building for Complex International Problems', in Nazli Choucri (ed.), Global Accord: Environmental Challenges and International Responses. Cambridge, MA: MIT Press. pp. 453-74.

Victor, David G., Raustiala, Kal and Skolnikoff, Eugene B. (eds) (1998) The Implementation and Effectiveness of International Environmental Commitments. Cambridge, MA: The MIT Press.

Vig, Norman J. and Axelrod, Regina S. (eds) (1999) The Global Environment: Institutions, Law and Policy. Washington, DC: CQ Press.

Waltz, Kenneth (1979) Theory of International Politics. Reading, MA: Addison-Wesley.

Wapner, Paul (1996) Environmental Activism and World Civic Politics. Albany: State University of New York Press.

Wendt, Alexander (1987) 'The Agent Structure Problem in International Relations Theory', International Organization, 41 (3): 335-70.

Wettestad, Jørgen (1995) 'Science, Politics and Institutional Design: Some Initial Notes on the Long-Range Transboundary Air Pollution Regime', Journal of Environment and Development, 4 (2): 165-83.

Wettestad, Jørgen (1999) Designing Effective Environmental Regimes: The Key Conditions. Cheltenham: Edward Elgar. 
World Commission on Environment and Development (1987) Our Common Future. New York: Oxford University Press.

World Resources Institute (1992-3) World Resources, 1992-93. New York: Basic Books.

Young, Oran (1989) International Cooperation: Building Regimes for Natural Resources and the Environment. Ithaca: Cornell University Press.

Young, Oran (1992) 'The Effectiveness of International Institutions: Hard Cases and Critical Variables', in James N. Rosenau and Ernst-Otto, Czempiel (eds), Governance Without Government: Change and Order in World Politics. New York: Cambridge University Press. pp. 160-94.

Young, Oran R. (1981) Natural Resources and the State: The Political Economy of Resource Management. Berkeley: University of California Press.

Young, Oran R. (1998a) Creating Regimes: Arctic Accords and International Governance. Ithaca: Cornell University Press.
Young, Oran R. (ed.) (1998b) Global Governance: Drawing Insights from the Environmental Experience. Cambridge, MA: MIT Press.

Young, Oran R. (1994) International Governance: Protecting the Environment in a Stateless Society. Ithaca: Cornell University Press.

Young, Oran R. (ed.) (1999a) Effectiveness of International Environmental Regimes: Causal Connections and Behavioral Mechanisms. Cambridge, MA: MIT Press.

Young, Oran R. (1999b) Governance in World Affairs. Ithaca: Cornell University Press.

Young, Oran R. and Osherenko, Gail (eds) (1993) Polar Politics: Creating International Environmental Regimes. Ithaca: Cornell University Press.

Zürn, Michael (1998) 'The Rise of International Environmental Politics: A Review of Current Research', World Politics, 50 (4): 617-49. 